\title{
Allergy and acute leukaemia in children with Down syndrome: a population study. Report from the Mexican inter-institutional group for the identification of the causes of childhood leukaemia
}

J C Núñez-Enríquez ${ }^{1}$, A Fajardo-Gutiérrez ${ }^{1}$, E P Buchán-Durán ${ }^{1}$, R Bernáldez-Ríos², A Medina-Sansón ${ }^{3}$, E Jiménez-Hernández ${ }^{4}$, R Amador-Sanchez ${ }^{5}$, J G Peñaloza-Gonzalez ${ }^{6}$, R Paredes-Aguilera ${ }^{7}$, F J Alvarez-Rodriguez ${ }^{8}$, V Bolea-Murga ${ }^{9}, J$ de Diego Flores-Chapa ${ }^{10}$, J Flores-Lujano ${ }^{1}$, V C Bekker-Mendez ${ }^{11}$, R Rivera-Luna ${ }^{12}$, M del Carmen Rodriguez-Zepeda ${ }^{2}$, A Rangel-López ${ }^{1}$, E M Dorantes-Acosta ${ }^{3}$, N Núñez-Villegas ${ }^{4}$, M M Velazquez-Aviña ${ }^{6}$, J R Torres-Nava ${ }^{8}$, N C Reyes-Zepeda ${ }^{10}$, R Cárdenas-Cardos ${ }^{13}$, L V Flores-Villegas ${ }^{10}$, A Martinez-Avalos ${ }^{13}$, F Salamanca-Gómez ${ }^{14}, \mathrm{C} \mathrm{Gorodezky}^{15}$, J Arellano-Galindo ${ }^{16}$ and J M Mejía-Aranguré ${ }^{\star, 1,14}$

\begin{abstract}
${ }^{1}$ Unidad de Investigación Médica en Epidemiologia Clínica, Hospital de Pediatría, Centro Médico Nacional (CMN) "Siglo XXI", Instituto Mexicano del Seguro Social (IMSS), Avenida Cuauhtémoc 330, Delegación Cuauhtémoc, México D.F. 06720, México; ${ }^{2}$ Servicio de Hematología, UMAE Hospital de Pediatría, Centro Médico Nacional (CMN) "Siglo XXI", Instituto Mexicano del Seguro Social (IMSS), Avenida Cuauhtémoc 330, Delegación Cuauhtémoc México D.F. 06720, México; ${ }^{3}$ Servicio de Onco-Hematologia, Hospital Infantil de México Federico Gómez, Secretaria de Salud (SSa), Calle Doctor Márquez 162, Colonia Doctores, Delegación Cuauhtémoc, México D.F. 06720, México; ${ }^{4}$ Servicio de Hematología Pediátrica, Hospital General "Gaudencio González Garza", Centro Médico Nacional (CMN) "La Raza", Instituto Mexicano del Seguro Social (IMSS), Calzada Vallejo y Jacarandas S/N Colonia La Raza, Delegación Azcapotzalco México D.F. 02990, México; ${ }^{5}$ Hospital General Regional "Carlos McGregor Sánchez Navarro", Instituto Mexicano del Seguro Social (IMSS), Avenida Gabriel Mancera No. 222, Colonia Del Valle, México D.F. 03100, México; 'ervicio de Onco-Pediatria, Hospital Juárez de México, Secretaria de Salud (SSa), Avenida Instituto Politécnico Nacional 5160, Colonia Magdalena de las Salinas, Delegación Gustavo A. Madero México D.F. 07760, México; ${ }^{7}$ Servicio de Hematología Pediátrica, Instituto Nacional de Pediatría (INP), Secretaria de Salud (SSa), Insurgentes Sur 3700, Letra C, Colonia Insurgentes Cuicuilco, Delegación Coyoacán, México D.F. 04530, México; ${ }^{8}$ Servicio de Oncología, Hospital Pediátrico de Moctezuma, Secretaria de Salud del D.F. Oriente 158-189, Colonia Moctezuma $2 a$ Sección, Delegación Venustiano Carranza, México D.F. 15530, México; ${ }^{9}$ Servicio de Hematología Pediátrica, Hospital General de México, Secretaria de Salud (SSa), Eje 2A Sur (Dr. Balmis) 148, Col. Doctores, Delegación Cuauhtémoc, México D.F. 06726, México; ${ }^{10}$ Servicio de Hematología Pediátrica, Centro Médico Nacional (CMN) '20 de Noviembre', Instituto de Seguridad Social al Servicio de los Trabajadores del Estado (ISSSTE), Félix Cuevas 540, Colonia Del Valle, Delegación Benito Juárez, México D.F. 03229, México; ${ }^{11}$ Unidad de Investigación Médica en Inmunología e Infectología, Hospital de Infectología Daniel Méndez Hernández, "La Raza" Instituto Mexicano del Seguro Social (IMSS), Calzada Vallejo y Jacarandas S/N Colonia La Raza, Delegación Azcapotzalco, México D.F. 02990, México; ${ }^{12}$ Subdireccion de Hemato/Oncología, Instituto Nacional de Pediatría (INP), Secretaria de Salud (SSa), Insurgentes Sur 3700, Letra C, Colonia Insurgentes Cuicuilco, Delegación Coyoacán, México D.F. 04530, México; ${ }^{13}$ Servicio de Oncología Pediátrica, Instituto Nacional de Pediatría (INP), Secretaria de Salud (SSa), Insurgentes Sur 3700, Letra C, Col. Insurgentes Cuicuilco, Delegación Coyoacán, México D.F. 04530, México; ${ }^{14}$ Coordinación de Investigación en Salud, Instituto Mexicano del Seguro Social (IMSS), Torre Academia Nacional de Medicina 4to piso, Av. Cuauhtémoc 330, Delegación Cuauhtémoc, México D.F. 06720, México; ${ }^{15}$ Departmento de Inmunología e Inmunogenética, Instituto de Diagnóstico y Referencia Epidemiológicas (InDRE), Secretaria de Salud (SSa), Benjamín Franklin \#132 Col. Escandón Delegación Miguel Hidalgo, México D.F. 11800, México and ${ }^{16}$ Laboratorio de Investigación en Hematología, Departamento de Hematología, Hospital Infantil de México Federico Gómez, Doctor Márquez 162, Col. Doctores, Delegación Cuauhtémoc, México D.F. 06720, México
\end{abstract}

Background: Allergies have been described as protective factors against the development of childhood acute leukaemia (AL). Our objective was to investigate the associations between allergy history and the development of AL and acute lymphoblastic leukaemia (ALL) in children with Down syndrome (DS).

Methods: A case-control study was performed in Mexico City. The cases $(n=97)$ were diagnosed at nine public hospitals, and the controls $(n=222)$ were recruited at institutions for children with DS. Odds ratios (OR) were calculated.

Results: Asthma was positively associated with AL development ( $O R=4.18 ; 95 \%$ confidence interval (CI): 1.47-11.87), whereas skin allergies were negatively associated $(\mathrm{OR}=0.42 ; 95 \% \mathrm{Cl}: 0.20-0.91)$.

Conclusion: Our findings suggest that allergies and AL in children with DS share biological and immune mechanisms. To our knowledge, this is the first study reporting associations between allergies and AL in children with DS.

*Correspondence: Dr JM Mejía-Aranguré, E-mail: juan.mejiaa@imss.gob.mx

Received 14 January 2013; revised 17 April 2013; accepted 22 April 2013; published online 21 May 2013

(C) 2013 Cancer Research UK. All rights reserved 0007-0920/13 
Acute leukaemia (AL) is the most common childhood cancer worldwide. Mexico City has one of the highest rates of AL at 57.6 cases per million; acute lymphoblastic leukaemia (ALL) is the most common subtype (85.1\%; Pérez-Saldivar et al, 2011).

Down syndrome (DS) is one of the most important childhood leukaemia-predisposing syndromes (Xavier and Taub, 2010). Children with DS have a 10- to 20-fold higher risk of developing AL compared with children without DS (Ross et al, 2005). The mechanism behind this increased susceptibility is not thoroughly known; however, it may be explained by the gene dosage effect caused by the additional copy of chromosome 21 , which could be involved in the malignant transformation of haematopoietic cells (Xavier and Taub, 2010). Mutations in several genes on chromosome 21 have been identified in leukaemia, and many of these genes have been recognised as encoding transcription factors that act at various stages of haematopoiesis. In addition, trisomy 21 contributes to the development of GATA1 mutations, which are involved in leukaemogenesis, particularly in acute megakaryoblastic leukaemia (Look, 2002; Malinge et al, 2009). In addition, it has been suggested that trisomy 21 increases the proliferation of normal lymphoid progenitors; however, it must be accompanied by other events, such as exposure to environmental factors, that could potentially cause leukaemia in DS children (Levanon et al, 2001; Mejía-Aranguré et al, 2003; Valladares et al, 2005; Mejia-Arangure et al, 2007; Rabson, 2010). Moreover, it has been proposed that allergies influence the development of childhood leukaemia. Different studies have been conducted in this field; however, their results are not conclusive, as different studies have concluded that allergies are risk or protective factors (Schüz et al, 2003; Spector et al, 2004; Rosenbaum et al, 2005; Söderberg et al, 2006; Hughes et al, 2007; Rudant et al, 2010; Chang et al, 2012). In addition, the mechanisms involved in the relationship between allergies and leukaemia are not completely understood.

Various immunological disorders have been described in children with DS (Kusters et al, 2009) that, along with these children's high susceptibility to AL, would provide additional evidence in the relationship between allergies and the development of AL.

The present study was conducted by the Mexican InterInstitutional Group for the Identification of the Causes of Childhood Leukaemia (MIGICCL). To our knowledge, this is the first study to evaluate the association between allergies and AL in DS children.

\section{MATERIALS AND METHODS}

The study has been described in greater detail elsewhere (FloresLujano et al, 2009) and is described briefly below. This casecontrol study was performed by the MIGICCL. The cases were DS patients diagnosed with $\mathrm{AL}$ and younger than 19 years old $(n=97)$. The diagnosis of AL was established by bone marrow aspirates and karyotype studies. The cases were recruited during two periods; the first corresponded to 1998-2005, when six public institutions in Mexico City participated under the auspices of the Instituto Mexicano de Seguro Social (IMSS), Instituto de Seguridad Social al Servicio de los Trabajadores del Estado and Secretaria de Salud. The second period was from 2006 to 2011 and incorporated three additional institutions. It is estimated that $97.5 \%$ of children with $\mathrm{AL}$ in Mexico City have attended at these public health institutions (Pérez-Saldivar et al, 2011). The control group consisted of children with DS children who were younger than 19 years old and did not have AL $(n=222)$. The controls were not matched with the cases according to other variables. At the time of the study, DS children residing in Mexico City could only be enrolled in two types of institutions (Centres of Multiple Attention and Specialized Centres), which offer specialised education to individuals with DS. There were 76 CMAs; however, children with DS from these institutions were not included in the present research because karyotype study was not part of the admission requirements. The specialised centres did require a karyotype study before children with DS were admitted; only three of the five specialised centres were selected because of logistic issues. From these centres, $78 \%$ of children with DS who were younger than 19 years were included in the present study; if any of the control children developed AL medical care was provided by one of the hospitals that served as sources of the cases. Down syndrome children with transient megakaryoblastic leukaemia and/or AML that developed after the resolution of transient neonatal leukaemia were not excluded from this study. The children's parents were interviewed by a trained nurse. Before the information was collected, an informed consent was obtained from the parents. After data were collected, they were compiled using a previously standardised questionnaire (Flores-Lujano et al, 2009). Each child's medical history (allergies, infections during the first year of life, cardiopathies, and hospitalisations) was explored. The cases' parents were required to indicate whether their children had allergies for at least 1 year before the diagnosis of $\mathrm{AL}$, whereas the control children's parents were asked about the occurrence of allergies at least 1 year before the interview. The parents were questioned about the specific type of allergy (asthma, rhinitis, skin allergy, and other allergies), emphasising the difference between allergy and infectious diseases. It is worth noting that the specific dates of diagnosis and symptoms of the allergic diseases were not explored in the present research. Stacking level was used as a proxy for socioeconomic status and was estimated by the number of people per room in a household and classified according to the criteria of Bronfman et al (1988): not crowded, up to 1.5 people per room; semi-crowded and crowded, $>1.6$ people per room. For the analysis, the last two categories were classified as a low stacking level.

Statistical analysis. Analyses were performed using SPSS IBM (Statistical Package for the Social Sciences, Inc., Version 21, Chicago, IL, USA). Each independent variable (skin allergy, rhinitis, bronchial asthma, and other allergies) was stratified for the control variables to control confounding factors that may alter the effect of independent variables. The covariates were dichotomised for statistical purposes. Odds ratios (OR) and 95\% confidence intervals (CI) were estimated for all independent variables and for DS children with and without ALL in unconditional logistic regression models. The variables included in the initial logistic regression models were as follows: gender, birth weight, birth order, breastfeeding, age at leukaemia diagnosis, infection during the first year of life, cardiopathies, stacking level, maternal information (age at child's birth, education, occupation, and smoking), and paternal information (education, occupation, and smoking). For the final logistic regression models, the variables infection during the first year of life, cardiopathies and paternal education were not included. Two interactions were identified during the statistical analyses (breastfeeding and age at leukaemia diagnosis); consequently, the studied population was divided by these variables.

\section{RESULTS}

Acute lymphoblastic leukaemia was observed in $65 \%$ of the cases. Breastfeeding was equally common among the cases and the controls $(P=0.86)$. Twenty-six per cent of the cases reported at least one allergic condition: asthma, rhinitis, skin allergy, or other allergies. The predominant type of allergy corresponded to the skin and was reported more frequently by controls than cases 
$(P=0.026)$. However, asthma was more frequently reported for cases than for controls $(P=0.004$; Table 1$)$.

Asthma was positively associated with AL development $(\mathrm{OR}=4.18 ; 95 \% \mathrm{CI}: 1.47-11.87)$, whereas skin allergy was negatively associated with $\mathrm{AL}(\mathrm{OR}=0.42 ; 95 \% \mathrm{CI}: 0.20$ to - 0.91). Asthma persisted as a risk factor for children with ALL; when the children were divided by whether they were breastfed (yes/no), the results were not statistically significant (Tables 2 and 3). After stratification by age at diagnosis, the result of this variable was similar (Supplementary Data). The protective effect observed for skin allergy was notable in children with AL and ALL who were not breastfed (Table 3). The same trend was observed for this variable after stratification by age at diagnosis, but statistical significance was not observed. Significant associations were not observed for rhinitis and other allergies in children with AL and ALL (Table 3 and Supplementary Table).

\section{DISCUSSION}

The results of the present study suggest that asthma is a risk factor for $\mathrm{AL}$ in children with DS, whereas skin allergies seemed to protect the population from AL. Children with DS are more vulnerable to the effects of environmental factors that have been associated with the development of AL (Mejía-Aranguré et al, 2003, 2007). In addition, our previous study found that early infections that have been regarded as protective factors against the development of childhood $\mathrm{AL}$ in the general population were risk factors for children with DS (Flores-Lujano et al, 2009). Thus, the intrinsic immune dysregulation that is well described in children with DS (Kusters et al, 2009) likely has a significant role in the association between allergic phenomena and AL.

The positive associations observed between asthma and ALL were similar to the findings of a study conducted in the western United States (Spector et al, 2004) and another conducted in Taiwan (Chang et al, 2012). However, other authors have reported negative associations (Schüz et al, 2003; Rosenbaum et al, 2005; Söderberg et al, 2006; Hughes et al, 2007; Rudant et al, 2010), as have two meta-analyses (Dahl et al, 2009; Linabery et al, 2010). Spector et al (2004) and Chang et al (2012) argued that the discrepancies between their results and those of other authors were caused by exposure data. The authors of these two studies obtained information from medical records, which are supposedly free of parental recall bias; whereas other authors and the present study administered questionnaires to the children's parents. It is important to highlight that one of the major advantages of using questionnaires in research is that they allow researchers to measure various and different variables using a single tool.

Furthermore, negative associations were observed between skin allergy and AL, and this trend remained when the group was divided according to the presence of ALL. This negative association is consistent with the findings of other studies (Schüz et al, 2003; Rosenbaum et al, 2005; Hughes et al, 2007; Rudant et al, 2010) and meta-analyses (Dahl et al, 2009; Linabery et al, 2010).

However, Spector et al (2004) and Chang et al (2012) showed contradictory results, for example, that a history of atopy or hives was positively associated with ALL. One factor that may have contributed to these differing results was the age of the studied population. Spector et al (2004) investigated children younger than 6 years old, and Chang et al (2012) included children between 1 and 10 years old; both of these study populations were younger than those of other studies. Another factor was the different definitions of skin manifestations of atopy.

In addition, in two recent reviews (Chang et al, 2009; Linabery et $a l, 2010)$, the authors have reported an inverse association
Table 1. Sample characteristics of children with Down syndrome and acute leukaemia from Mexico City

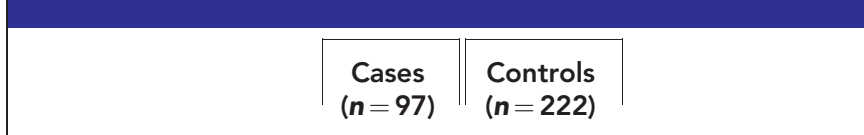

\begin{tabular}{|c|c|c|c|c|c|}
\hline Variables & $\mathbf{n}$ & $\%$ & $\mathrm{n}$ & $\%$ & OR (Cl 95\%) \\
\hline \multicolumn{6}{|l|}{ Gender } \\
\hline Female & 52 & 53.6 & 102 & 45.9 & \\
\hline Male & 45 & 46.4 & 120 & 54.1 & \\
\hline Weight at birth $(>2600 \mathrm{~g})$ & 60 & 62.5 & 112 & 51.4 & $0.63(0.38-1.03)$ \\
\hline Firstborn child & 22 & 22.7 & 74 & 33.3 & $0.58(0.33-1.01)$ \\
\hline Breastfed & 63 & 64.9 & 142 & 64 & $1.04(0.63-1.71)$ \\
\hline Age $>6$ years $^{a}$ & 46 & 47.4 & 128 & 57.7 & $0.66(0.41-1.07)$ \\
\hline Stacking & 58 & 59.8 & 76 & 34.2 & $2.85(1.74-4.67)$ \\
\hline $\begin{array}{l}\text { Infection during the first } \\
\text { year of life }\end{array}$ & 24 & 24.7 & 57 & 25.7 & $0.95(0.54-1.65)$ \\
\hline Cardiopathies & 13 & 13.4 & 68 & 30.6 & $0.35(0.18-0.67)$ \\
\hline
\end{tabular}

\section{Allergy history}

\begin{tabular}{|l|c|c|c|c|c|}
\hline Bronchial asthma & 10 & 10.3 & 6 & 2.7 & $4.18(1.47-11.87)$ \\
Rhinitis & 6 & 6.2 & 19 & 8.5 & $0.69(0.26-1.78)$ \\
Skin allergy & 9 & 9.3 & 43 & 19.4 & $0.42(0.20-0.91)$ \\
Other allergies & 12 & 12.4 & 27 & 12.2 & $1.03(0.49-2.13)$ \\
Overall allergies & 25 & 25.8 & 73 & 32.9 & $0.69(0.40-1.17)$ \\
\hline
\end{tabular}

Abbreviations: $\mathrm{Cl}=$ confidence interval; $\mathrm{OR}=$ odds ratio.

${ }^{\mathrm{a}} \mathrm{Age}>6$ years: age at leukaemia diagnosis for cases or age at interview for controls.

Table 2. Logistic regression model for allergy history in children with DS \begin{tabular}{|l|l|}
\hline Children with AL Children with ALL \\
\hline
\end{tabular}

\begin{tabular}{|l|c|c|c|c|}
\hline Variables & OR & Cl 95\% & OR & Cl 95\% \\
\hline Skin allergy & 0.42 & $0.18-0.97$ & 0.26 & $0.08-0.83$ \\
\hline Rhinitis & 1.07 & $0.34-3.32$ & 1.01 & $0.24-4.20$ \\
\hline Bronchial asthma & 3.29 & $0.97-11.14$ & 4.24 & $1.01-17.79$ \\
\hline Other allergic diseases & 1.56 & $0.65-3.75$ & 1.84 & $0.71-4.72$ \\
\hline Overall allergies & 0.75 & $0.39-1.42$ & 0.83 & $0.39-1.75$ \\
\hline
\end{tabular}

Abbreviations: $\mathrm{AL}=$ acute leukaemia; $\mathrm{ALL}=$ acute lymphoblastic leukaemia; $\mathrm{Cl}=$ confidence interval; $\mathrm{DS}=$ Down syndrome; $\mathrm{OR}=$ odds ratio. Odds ratios were adjusted for the following variables: gender, weight at birth, birth order, breastfeeding, age at diagnosis of leukaemia, stacking level, maternal information (age at child's birth, education, occupation, and smoking), and paternal information (occupation and smoking).

between allergies and childhood AL. It has been argued that very few studies have researched this relationship and their results must be interpreted in the light of certain limitations, such as exposure data and latency period, which affect study results (Linabery et al, 2010).

Moreover, the opposite results observed in the present research suggest that asthma is a risk factor for the development of AL in DS children, whereas skin allergy is a protective factor. One possible explanation for our observations is the radiological studies and treatments that were administered to the children; however, these variables were not explored in the present study.

In the present study, exposures were assessed only via interview; it is possible that asthma was misclassified, as it can 
Table 3. Logistic regression model for allergy history in children with DS by breastfeeding and ALL

\begin{tabular}{|c|c|c|c|c|c|c|c|c|}
\hline \multirow[b]{3}{*}{ Variables } & \multicolumn{4}{|c|}{$\begin{array}{l}\text { Children with AL } \\
\text { Breastfeeding }\end{array}$} & \multicolumn{4}{|c|}{$\begin{array}{l}\text { Children with ALL } \\
\text { Breastfeeding }\end{array}$} \\
\hline & \multicolumn{2}{|r|}{ Yes } & \multicolumn{2}{|c|}{ No } & \multicolumn{2}{|c|}{ Yes } & \multicolumn{2}{|c|}{ No } \\
\hline & OR & $\mathrm{Cl} 95 \%$ & OR & $\mathrm{Cl} 95 \%$ & OR & $\mathrm{Cl} 95 \%$ & OR & $\mathrm{Cl} 95 \%$ \\
\hline Skin allergy & 1.22 & $0.26-5.67$ & 0.20 & $0.06-0.70$ & 1.21 & $0.22-6.62$ & 0.06 & $0.01-0.60$ \\
\hline Rhinitis & 16.47 & $1.29-209.13$ & 0.42 & $0.08-2.04$ & 16.45 & $0.85-316.11$ & 0.25 & $0.02-2.76$ \\
\hline Bronchial asthma & 2.47 & $0.39-15.74$ & 2.75 & $0.47-15.90$ & 2.05 & $0.21-20.03$ & 5.64 & $0.71-44.76$ \\
\hline Other allergic diseases & 1.00 & $0.14-7.12$ & 1.94 & $0.66-5.67$ & 1.69 & $0.26-10.83$ & 2.51 & $0.71-8.85$ \\
\hline Overall allergies & 0.98 & $0.27-3.47$ & 0.63 & $0.28-1.44$ & 1.08 & $0.27-4.20$ & 0.77 & $0.29-2.08$ \\
\hline
\end{tabular}

be confounded with other respiratory infections, resulting in overreporting by parents. The frequencies of wheezing and asthma in general population are $\sim 36.1 \%$ and $55.5 \%$, respectively, (Wright, 2002). In children with DS, however, the frequency of wheezing has been reported as between 18.5 and $36 \%$, and the reported frequency of asthma is between 3.1 and $19.4 \%$ (Munoz-Lopez, 2011; Weijerman et al, 2011). It is worth noting that these frequencies were determined via questionnaire. In the present investigation, the frequency of asthma was $2.7 \%$ and $10.4 \%$ for controls and cases, respectively; therefore, the frequency observed for asthma in this study was not higher than that reported in the studies mentioned, and the possibility of over-report is low.

The reported frequency of skin allergy in children with DS is between 9.2 and 15.4\% (Munoz-Lopez, 2011; Weijerman et al, 2011). In the present study, the frequency was $9.4 \%$ and $19.5 \%$ for cases and controls, respectively; thus, the frequencies determined in this study were similar to those previously reported.

It is worth noting that in the present study, the same questionnaire was used for cases and controls; if the parents made mistakes when remembering the details of an asthma or skin allergy diagnosis, the mistakes were equally likely for both groups. This would provoke a non-differential misclassification bias with a possible underestimation of the association, and the associations found would be higher. Moreover, we cannot presume that cases' parents over-reported asthma and under-reported skin allergy; if asthma was confounded with respiratory infections and/or cardiopathies, both would have behaved as confounding factors or interaction variables in the analysis, which was not the case. In the stratified analysis, when the infections during the first year of life were taken into account, the trend of asthma and skin allergy remained positively and negatively associated with AL, respectively, $\left(P=0.616\right.$ and $P=0.289$, respectively; $P$ values of the $\chi^{2}$ test for heterogeneity). In addition, a similar trend was observed when cardiopathies were included in the stratified analysis $(P=0.738$ and $P=0.214$, respectively; $P$ values of the $\chi^{2}$ test for heterogeneity). The possibility of a selection bias in the present study was low because it is estimated that $97.5 \%$ of children with $\mathrm{AL}$ in Mexico City attend the nine public institutions that participated in this research (Pérez-Saldivar et al, 2011). Regarding the controls, $78 \%$ of the population younger than 19 years old from the three participating centres was included in the research (Flores-Lujano et al, 2009). All of the parents of cases and controls answered the questionnaire.
The association between allergies and AL in children suggests common biological mechanisms, which have been described in the context of two hypotheses: the antigenic stimulation hypothesis and the immunosurveillance hypothesis (Söderberg et al, 2004). To explain the role of allergies as a risk factor for cancer, is worth considering the antigenic stimulation hypothesis, which proposes that the chronic stimulation of the immune system will provoke randomly occurring pro-oncogenic mutations in actively dividing cells (Söderberg et al, 2004). In comparison, allergies as protective factors can be explained in terms of the immune-surveillance hypothesis, which suggest that allergic diseases enhance the immune system's ability to detect and eliminate neoplastic cells (Söderberg et al, 2004). We suggest that another possible hypothesis is the adrenal hypothesis (Schmiegelow et al, 2008), which proposes that infections produce changes in the hypothalamus-pituitary-adrenal axis and subsequently an elevation in plasmatic cortisol, provoking the elimination of leukaemic and preleukaemic cells. This mechanism would be possible in allergic conditions because the drugs commonly used to treat allergies include corticosteroids (Allergy UK British Allergy Foundation, 2012), which could provide the same protective effect against the development of AL that early infections provide.

In contrast, it has been reported that children with wheezing caused by common viral infections (rhinovirus and respiratory syncytial virus (RSV)) are at increased risk of developing asthma (Boyce et al, 2009). In addition, the predisposition to these infections is determined by interactions with some genes (Çalışkan et al, 2013). Children with DS have genetic characteristics that make them more susceptible to infections, including those caused by RSV (Bloemers et al, 2010; Weijerman et al, 2011; Zachariah et al, 2012). Therefore, DS children exposed to these viruses may be at increased risk of developing asthma and subsequently, according to the results of the present study, for developing AL. However, this hypothesis requires further research to elucidate the relationship between genetic susceptibility to the development of RSV infections that in turn increase the risk of asthma and possibly AL in children with DS.

The major strength of the present research is that it is the first to report associations between allergies and AL in children with DS, a population highly susceptible to AL. Our results suggest that asthma is risk factor for AL in children with DS, whereas skin allergy appeared to be protective factor. These results must be interpreted in the light of some limitations. Although the most relevant results in the present study were consistent with previous 
research, future studies are required to elucidate the association between allergies and AL in children with DS.

\section{ACKNOWLEDGEMENTS}

We thank the Coordinacion de Investigacion en Salud of the IMSS for sponsoring the publication. This project was partially funded by the Instituto Mexicano del Seguro Social (2005/1/I/078; FIS/IMSS/ PROT/C2007/056; FIS/IMSS/PROT/G10/846), by the Consejo Nacional de la Ciencia y la Tecnologia (CONACYTSALUD 2007-1-71223/FIS/IMSS/PROT/592), and by the Fondo Sectorial de Investigacion para la Educacion (CB-2007-1-83949/FIS/IMSS/ PROT/616).

\section{REFERENCES}

Allergy UK British Allergy Foundation (2012) Allergy Medications http:// www.allergyuk.org/search.php?searchtext $=$ cortisol\&x $=0 \& y=0$ (accessed 21 December, 2012).

Bloemers BLP, Van Furth AM, Weijerman ME, Gemke RJBJ, Broers CJM, Kimpen JLL, Bont L (2010) High incidence of recurrent wheeze in children with down syndrome with and without previous respiratory syncytial virus lower respiratory tract infection. Pediatr Infect Dis J 29: $39-42$.

Boyce Ja, Broide D, Matsumoto K, Bochner BS (2009) Advances in mechanisms of asthma, allergy, and immunology in 2008. J Allergy Clin Immunol 123: 569-574.

Bronfman M, Guiscafré H, Castro V, Castro R, Gutiérrez G (1988) Strategies for improving the therapeutic patterns used in acute diarrhea in primary medical care units. II. The measurement of inequality: a methodologic strategy, analysis of the socioeconomic features of the sample. Arch Invest Med (Mex) 19: 351-360.

Çalışkan M, Bochkov YA, Kreiner-Møller E, Bønnelykke K, Stein MM, Du G, Bisgaard H, Jackson DJ, Gern JE, Lemanske RF, Nicolae DL, Ober C (2013) Rhinovirus wheezing illness and genetic risk of childhood-onset asthma. N Engl J Med 368: 1398-1407.

Chang JS, Tsai Y-W, Tsai C-R, Wiemels JL (2012) Allergy and risk of childhood acute lymphoblastic leukemia: a population-based and recordbased study. Am J Epidemiol 176: 970-978.

Chang JS, Wiemels JL, Buffler PA (2009) Allergies and childhood leukemia. Blood Cells Mol Dis 42: 99-104.

Dahl S, Schmidt LS, Vestergaard T, Schüz J, Schmiegelow K (2009) Allergy and the risk of childhood leukemia: a meta-analysis. Leukemia 23: 2300-2304.

Flores-Lujano J, Perez-Saldivar ML, Fuentes-Pananá EM, Gorodezky C, Bernaldez-Rios R, Del Campo-Martinez MA, Martinez-Avalos A, MedinaSanson A, Paredes-Aguilera R, De Diego-Flores Chapa J, Bolea-Murga V, Rodriguez-Zepeda MC, Rivera-Luna R, Palomo-Colli MA, RomeroGuzman L, Perez-Vera P, Alvarado-Ibarra M, Salamanca-Gómez F, Fajardo-Gutierrez A, Mejía-Aranguré JM (2009) Breastfeeding and early infection in the aetiology of childhood leukaemia in Down syndrome. $\mathrm{Br} \mathrm{J}$ Cancer 101: 860-864.

Hughes AM, Lightfoot T, Simpson J, Ansell P, McKinney Pa, Kinsey SE, Mitchell CD, Eden TOB, Greaves M, Roman E (2007) Allergy and risk of childhood leukaemia: results from the UKCCS. Int J Cancer 121: 819-824.

Kusters Maa, Verstegen RHJ, Gemen EFa, De Vries E (2009) Intrinsic defect of the immune system in children with Down syndrome: a review. Clin Exp Immunol 156: 189-193.

Levanon D, Glusman G, Bangsow T, Ben-Asher E, Male DA, Avidan N, Bangsow C, Hattori M, Taylor TD, Taudien S, Blechschmidt K, Shimizu N, Rosenthal A, Sakaki Y, Lancet D, Groner Y (2001) Architecture and anatomy of the genomic locus encoding the human leukemia-associated transcription factor RUNX1/AML1. Gene 262: 23-33.

Linabery AM, Jurek AM, Duval S, Ross JA (2010) The association between atopy and childhood/adolescent leukemia: a meta-analysis. Am J Epidemiol 171: 749-764.
Look AT (2002) A leukemogenic twist for GATA1. Nat Genet 32: 83-84. Malinge S, Izraeli S, Crispino JD (2009) Insights into the manifestations, outcomes, and mechanisms of leukemogenesis in Down syndrome. Blood 113: $2619-2628$.

Mejía-Aranguré JM, Fajardo-Gutiérrez A, Flores-Aguilar H, Martínez-García MC, Salamanca-Gómez F, Palma-Padilla V, Paredes-Aguilera R, Bernáldez-Ríos R, Ortiz-Fernández A, Martínez-Avalos A, Gorodezky C (2003) Environmental factors contributing to the development of childhood leukemia in children with Down's syndrome. Leukemia 17: 1905-1907.

Mejia-Arangure JM, Fajardo-Gutierrez A, Perez-Saldivar ML, Gorodezky C, Martinez-Avalos A, Romero-Guzman L, Campo-Martinez MA, FloresLujano J, Salamanca-Gomez F, Velasquez-Perez L (2007) Magnetic fields and acute leukemia in children with Down syndrome. Epidemiology 18: $158-161$.

Munoz-Lopez F (2011) Pediatria, sindrome de Down y patologia alergica. Int Med Rev Down Syndrome 15: 8-13.

Pérez-Saldivar ML, Fajardo-Gutiérrez A, Bernáldez-Ríos R, Martínez-Avalos A, Medina-Sanson A, Espinosa-Hernández L, Flores-Chapa JDD, Amador-Sánchez R, Peñaloza-González JG, Alvarez-Rodríguez FJ, BoleaMurga V, Flores-Lujano J, Rodríguez-Zepeda MDC, Rivera-Luna R, Dorantes-Acosta EM, Jiménez-Hernández E, Alvarado-Ibarra $M$, Velázquez-Aviña MM, Torres-Nava JR, Duarte-Rodríguez DA, ParedesAguilera R, Del Campo-Martínez MDLÁ, Cárdenas-Cardos R, AlamillaGalicia PH, Bekker-Méndez VC, Ortega-Alvarez MC, Mejia-Arangure JM (2011) Childhood acute leukemias are frequent in Mexico City: descriptive epidemiology. BMC Cancer 11: 355.

Rabson AB (2010) Trisomy 21 leukemias: finding the hits that matter. Oncogene 29: 6099-6101.

Rosenbaum PF, Buck GM, Brecher ML (2005) Allergy and infectious disease histories and the risk of childhood acute lymphoblastic leukaemia. Paediatr Perinat Epidemiol 19: 152-164.

Ross Ja, Blair CK, Olshan AF, Robison LL, Smith FO, Heerema Na, Roesler M (2005) Periconceptional vitamin useand leukemia risk in children with Down syndrome: a Children's Oncology Group study. Cancer 104: 405-410.

Rudant J, Orsi L, Menegaux F, Petit A, Baruchel A, Bertrand Y, Lambilliotte A, Robert A, Michel G, Margueritte G, Tandonnet J, Mechinaud F, Bordigoni P, Hémon D, Clavel J (2010) Childhood acute leukemia, early common infections, and allergy: the ESCALE Study. Am J Epidemiol 172: 1015-1027.

Schmiegelow K, Vestergaard T, Nielsen SM, Hjalgrim H (2008) Etiology of common childhood acute lymphoblastic leukemia: the adrenal hypothesis. Leukemia 22: 2137-2141.

Schüz J, Morgan G, Böhler E, Kaatsch P, Michaelis J (2003) Atopic disease and childhood acute lymphoblastic leukemia. Int J Cancer 105: 255-260.

Söderberg KC, Hagmar L, Schwartzbaum J, Feychting M (2004) Allergic conditions and risk of hematological malignancies in adults: a cohort study. BMC Public Health 4: 51.

Söderberg KC, Jonsson F, Winqvist O, Hagmar L, Feychting M (2006) Autoimmune diseases, asthma and risk of haematological malignancies: a nationwide case-control study in Sweden. Eur J Cancer 42: 3028-3033.

Spector L, Groves F, DeStefano F, Liff J, Klein M, Mullooly J, Black S, Shinefield H, Ward J, Marcy M (2004) Medically recorded allergies and the risk of childhood acute lymphoblastic leukaemia. Eur J Cancer 40: 579-584.

Valladares A, Palma-Padilla V, Mejía-Aranguré JM, Guevara-Yánez R, Lerma-Reyes A, Salamanca-Gómez F (2005) Cytogenetic studies in children with Down syndrome and acute leukemia. Leuk Res 29: 1241-1246.

Weijerman ME, Brand PLP, Van Furth Ma, Broers CJM, Gemke RJBJ (2011) Recurrent wheeze in children with Down syndrome: is it asthma? Acta Paediatr 100: e194-e197.

Wright AL (2002) Epidemiology of asthma and recurrent wheeze in childhood. Clin Rev Allergy Immunol 22: 33-44.

Xavier AC, Taub JW (2010) Acute leukemia in children with Down syndrome. Haematologica 95: 1043-1045.

Zachariah P, Ruttenber M, Simões EAF (2012) Down syndrome and hospitalizations due to respiratory syncytial virus: a population-based study. J Pediatr 160: 827-831.e1.

Supplementary Information accompanies this paper on British Journal of Cancer website (http://www.nature.com/bjc) 